\title{
Language Teachers and Their Trajectories Across Technology-Enhanced Language Teaching: Needs and Beliefs of ESL/EFL Teachers
}

\author{
Banafsheh Karamifar, Aline Germain-Rutherford, \\ Sarah Heiser, Martina Emke, Joseph Hopkins, \\ Pauline Ernest, Ursula Stickler, \& Regine Hampel
}

In this article, we present the initial results of the first phase of our international Research Network, which sets out to revisit the current needs of language teachers in terms of training to achieve the integration of technology within their educational contexts. We focus on the type of needs and their order of priority from the viewpoint of English as a Second/Foreign Language (ESL/EFL) teachers and suggest some recommendations for training programs. These data, collected via an online questionnaire distributed in several countries, were analyzed quantitatively and qualitatively in relation to participants' perceptions of needs regarding language education technology, as well as participants' perceptions of the "ideal" teacher, and their relation to the use of technology. Results indicate that despite overall satisfaction regarding training received, many teachers mention their need for a posttraining follow-up. They also express interest in developing "learning task design" skills and in exploring course management platforms such as Moodle. Furthermore, while most participants fully or partially agree with the relationship between technology and excellence in language teaching, their definition of the "ideal" language teacher rarely includes the use of technology. A shift in "ideal" teacher beliefs seems, therefore, necessary for better adoption and use of technology in language education.

Dans cet article, nous présentons les premiers résultats de la phase initiale d'une étude effectuée par notre Réseau international de recherche, qui vise à réexaminer les besoins actuels des professeurs de langues en termes de formation sur l'intégration de la technologie dans leur propre contexte éducatif. Nous mettons l'accent sur les types de besoins et leur ordre de priorité du point de vue des professeurs d'anglais langue seconde/langue étrangère (ESL/EFL) en proposant plusieurs recommandations pour les programmes de formation. Les données ont été collectées par le biais d'un questionnaire en ligne distribué dans plusieurs pays, et ont fait l'objet d'une analyse quantitative et qualitativement par rapport aux perceptions des participants sur les besoins en matière de technologie de l'enseignement des langues. Le questionnaire interroge aussi les participants sur leur perception de l'enseignant "idéal », et leur relation avec l'utilisation de la technologie. Les 
résultats indiquent que malgré la satisfaction générale concernant la formation reçue, de nombreux enseignants mentionnent leur besoin d'avoir un suivi. Ils expriment également leur intérêt à développer des compétences en conception de tâches d'apprentissage et à explorer des plates-formes de gestion des cours comme Moodle. En outre, bien que la plupart des participants reconnaissent un lien positif entre la technologie et l'excellence dans l'enseignement des langues, leur définition du professeur de langues «idéal » inclut rarement l'utilisation de la technologie. Il semble donc nécessaire que les croyances relatives à la définition du professeur de langue «idéal » évoluent afin de favoriser l'adoption et l'usage de la technologie dans l'enseignement de langues.

KEYWORDS: ESL/EFL language teachers, digital training needs, ideal language teacher, continuing professional development

\section{Introduction}

In the last decade, expectations have risen in line with the rapid growth of information and communication technology (ICT) and the benefits it promises for educational purposes: ubiquitous learning, anyhow, anywhere, anytime (Andrews et al., 2011); increased potential for action-oriented learning approaches and collaborative learning (Thomas, 2016); positive impact on student motivation (Dörnyei, 2001; Kessler, 2018; Reinders \& Hubbard, 2012); as well as the promising use of robotic, virtual, and augmented realities, along with artificial intelligence, to customize and personalize learning (Bonner \& Reinders, 2018; Reich-Stiebert \& Eyssel, 2016). Today's students tend to view technology as critical to their learning experiences (Bain \& Ross, 1999; Bransford et al., 2000; Brooks, 2016; Bullen \& Morgan, 2015; Organisation for Economic Co-operation and Development [OECD], 2012, 2015, 2019; Sivin-Kachala \& Bialo, 2000).

As digital tools and applications develop at an ever-increasing pace and learner expectations change, limiting digital skills development to preservice, institution-based teacher training, as is frequently the case in formal language educator training programs, is no longer sufficient. Instead, continuing professional development (CPD) has gained importance for (language) teaching professionals to enable them to keep abreast of the multiple changes occurring in all areas of communication. For researchers (Putnam \& Borko, 2000; Smylie et al., 2001; Darling-Hammond \& Ball, 1997; Loucks-Horsley et al., 1998; Little, 1993), practitioners (e.g., Wilson \& Berne, 1999), and policymakers (e.g., National Commission on Mathematics and Science Teaching for the 21st Century, 2000),

professional development is viewed as a career-long, context-specific, continuous endeavor that is guided by standards, grounded in 
the teacher's own work, focused on student learning, and tailored to the teacher's stage of career development. ... It is a collaborative effort, in which teachers receive support from peer networks, local administration, teacher educators, and outside experts. (Schlager \& Fusco, 2004, p. 124)

In its report on the 2018 Teaching and Learning International Survey (TALIS), conducted in 48 countries, the OECD indicates not only an increase in the frequency of ICT use by teachers and students for class activities, but also rising "participation rates in professional development activities including ICT skills for teaching" (OECD, 2019, p. 29). A number of continuing professional training initiatives have been developed over the past years (e.g., Cutrim Schmid, 2017; Hampel \& Stickler 2015; ICT Cluster, 2010) to support language teachers' development of digital skills for the 21st century. However, the extent to which institutions value these skills and teachers' professional development can vastly differ depending on geographical, political, and socioeconomic contexts, and these still need to be studied. In addition, it is crucial to regularly revisit language teachers' training needs in terms of technology to ensure that the training offered by institutions aligns with the teachers' actual needs. Furthermore, the training available for language teachers is often designed around a perceived notion of a "good" or even "ideal" teacher, a notion that can be culturally specific and strongly impact the expected learning outcomes of the training. The degree of belief in the relationship between excellence in language teaching and the integration of technology can also influence the level of openness to the integration of technology in an educational context (Dexter \& Anderson, 2002; Ertmer et al., 1999; Newhouse, 2001; Zhao et al., 2002). All these issues are key elements that need to be taken into account when considering the relevance of CPD in digital literacy for language teachers.

Founded in 2018, the International Association of Applied Linguistics (AILA) Research Network titled "Perspectives and Trajectories of the Language Teacher in the 21st Century" (TPLang21) brings together 35 established language educators and researchers from 15 countries across five continents, who work on the integration of ICT in language education and (self)empowering methods of continuing professional development.

This international network aims to arrive at a detailed picture of the landscape of language teacher training in terms of digital skills needs and development, according to target culture, culture of origin, and teaching and learning cultures. It also aims to identify and compare beliefs about the "ideal" language teacher from different cultural perspectives and to examine its role in language teachers' and educators' openness to technology. The specific objectives of the network include the following:

- to collect information about CPD programs, focusing on ICT and/or selfempowerment ${ }^{1}$ of language teachers, 
- to compare different, international approaches to CPD,

- to collect information about perception of language teacher training needs,

- to compare beliefs about the "ideal" teacher from an intercultural perspective.

\section{Literature Review and Frameworks}

In this section, we present some previous research on the following key concepts: affordance of technology in language teachers' preparation; language teachers' training needs in terms of technology integration, technology and teacher beliefs; and the notion of the ideal language teacher.

\section{Affordances of Technology in Language Teacher Training}

An important well-documented aspect of teachers' learning about the use of technology involves developing their ability to assess digital educational resources and to reflect on the opportunities these tools offer to enhance student learning, such as how these tools engage students in learning experiences that will encourage them to practice language extensively. Hence, the ability to identify the affordances of new technological tools becomes indispensable in teacher preparation programs (Haines, 2015; Hampel \& Stickler, 2005; Kessler, 2010).

Haines (2015) defines affordance as "the potential that teachers perceive in a particular technology tool that will support learning and teaching activities in their educational contexts" (p. 166). Based on Egbert et al. (2011) and Sharp (2011), Haines reiterates that in the continuing professional development of language teachers aimed at integrating technology into classroom practices, it is less important to encourage teacher trainees to learn how to use technologies than involving them in evaluating the way technologies are used. Haines demonstrates how, even given the same contexts, perceptions differ among teachers through repeated classroom experience with the use of tools over time, and these perceptions are transferred to the way each new tool is used. She reports on the impacts of previous uses of technology in the "learning affordance" of new tools, and advantages in informal learning such as participatory practices (Kessler, 2006; Kessler, 2007), with reference to research and other teachers' experiences in broadening perceptions of affordances. In her research, teachers' beliefs are significant in contributing to the affordances they perceive.

Egbert et al. (2011, p. 191) argue that there is a need for more research into technology use algorithms by language teachers, to define more precisely the areas that affect teacher uses of technology, the integration of new technologies, and their affordances in practice. For Egbert et al., a part of professional 
teachers' competences is "techno-pedagogical" competence, which is manifested in a teacher's capacity to adapt the potential of a tool to pedagogical objectives and students' learning characteristics.

Guichon and Hauck (2011, p. 191) list a number of skills for a more precise definition of "techno-pedagogical competencies" as part of a language teacher's professional identity. The list contains the following abilities: (a) assess the potential and limits of technologies for language and culture learning; (b) carry out a needs analysis to introduce adequate technologies at appropriate moments in a pedagogical sequence; (c) handle basic tools and applications, and solve simple technical problems; (d) design appropriate tasks; (e) design for interactions within and outside the classroom in view of the technologies' affordances; (f) rethink the contract with learners and colleagues; and (g) manage time and optimize the integration of technologies.

However, Sharp's (2011) study states that teachers have difficulty adapting technology tools to pedagogical objectives and, therefore, in mastering techno-pedagogical abilities. Identifying differences and similarities in affordances that teachers perceive is, therefore, an important part of extending techno-pedagogical knowledge into language teaching training. Several other studies also demonstrate that technologies and the opportunities they offer are a challenge for inservice language teachers (Haines, 2015; Blake, 2008; Egbert et al., 2011; Hanson-Smith, 2006; Hubbard, 2007; Robb, 2006). Language teachers, especially, need to identify the affordances of new tools and understand how they can support learning in the language classroom (Kessler, 2010).

\section{Language Training Needs in Terms of Technology Integration}

By summarizing the interventions of several researchers in the integration of technology in language teaching/learning, Sauro and Chapelle (2017) emphasize "the multimodal nature of the language abilities that need to be taught and investigated in language teaching and research in order to engage with the reality of the world in which students learn and use language" (p. 459). According to the authors, this multimodal nature of the language implies that "the continuous innovative nature of language teaching and learning" (p. 459) becomes one effective language teaching characteristic. Inspired by a discussion by Sykes (2017), the authors state that language study today would be even better characterized by the term "langua-technoculture" (Sauro \& Chapelle, p. 460). Indeed, "the technology-mediated nature of so much of learners' second language experience" fosters their intercultural competence and equips them to participate in today's life interactions "through, and around digital discourse spaces such as Facebook, YouTube, Twitter, and fanfiction sites" (Sykes, 2017, p. 128).

Hubbard and Levy (2006b) identify a number of general needs in their edited book on teacher education in computer-assisted language learning 
(CALL), such as "the need for both technical and pedagogical training in CALL"; "the recognition of the limits of formal teaching because the technology changes too rapidly"; "the need to connect CALL education to authentic teaching settings, especially ones where software, hardware, and technical support differ from the ideal"; "the value of having CALL permeate the language teacher education curriculum rather than appear solely in a standalone course" (pp. 10-16).

Stickler and Emke (2015) also highlight the need for high quality, appropriate, and ongoing forms of training (online, blended, and/or face-to-face) for language teachers, both in using new tools and in ensuring the pedagogical considerations. Hampel and Stickler (2015) report on a 2008 needs analysis of language teachers in Europe and confirm the need for teachers to develop their ability to carry out their own research, to self-train, and successfully teach, using technology as a pedagogically transformative practice that has the potential to empower both students and teachers.

Germain-Rutherford and Ernest (2015) examine the results of several surveys on the needs of language educators in Europe, conducted from 2008 to 2014. The authors conclude that language teachers want to explore, in decreasing order of importance, Web 2.0 tools to foster learning via social interactions and collaboration, tools to create digital audio documents, and course management platforms to organize and distribute course material. In their research, wikis and blogs were the most frequently mentioned tools participants wanted to use, for collaborative and interactive learning tasks involving students from within a class and online students from other places around the world. Several participants expressed the need to explore course management platforms such as Moodle. This research suggests that teachers want to gain confidence in successfully integrating digital tools in their classroom. However, the 2018 TALIS data show that, currently, "there is limited preparation and support available for teachers that could enable them to implement innovative practices in their instruction" (OECD, 2019, p. 29). The same study also recommends that training in ICT skills for teaching should reflect how technology can amplify great teaching and empower teachers to become better instructors" (OECD, 2019, p. 31).

Kessler (2018) highlights that technology training is either completely neglected in language teacher preparation or is often "inadequate, inappropriate, irrelevant, or outdated" (p. 215). Kessler (2018) also states that even though the integration of future technologies can revolutionize language teaching, language teacher technology training is based solely on existing software. Furthermore, in view of the multiplicity of options for using technology to improve language learning, teachers face challenges in choosing the appropriate technology for their purpose. He also suggests that there is a disconnect between the insights from research in language education and the practices of language teacher training. To fill these gaps, Kessler (2018) classifies and lists the range of current, emerging, and future-trend technol- 
ogy-mediated tools ${ }^{2}$ that can be incorporated in language teaching/learning (face-to-face, online, synchronous, and asynchronous uses) as well as in language teacher preparation, and suggests some affordances of these tools for language teachers.

\section{Technology Integration Practices and Teacher Beliefs}

In recent years, many models of technology integration in education have been suggested to foster a systematic improvement and effective use of technology by teachers. For example, the Technological Pedagogical Content Knowledge (TPACK; changed from TPCK in Thompson \& Mishra, 2007) model, suggested by Koehler and Mishra (2006, 2009), seeks to explain "what knowledge and skills teachers lack and what professional development" should be targeted so as to improve the use of technology in education (Ch. M. Kim et al., 2013, p. 75). However, TPACK still does not explain why teachers, even with enough technological knowledge, use it differently (Ch. M. Kim et al., 2013).

The Technological Acceptance Model (TAM) sought to fill this gap, by helping technology and education researchers to understand factors and mechanisms of teachers' technology use (Scherer et al., 2018; Liu et al., 2019). TAM suggests two factors, "Perceived Usefulness" and "Perceived Ease of Use," as key predictors of technology adoption. However, researchers criticize this model for its focus on "intentions to use technology" and not verifying "the actual technology-use behavior" of teachers (Bagozzi, 2007; Liu et al., 2019). These researchers reject TAM's assumption that teachers' intention to use technology will lead to their acting on this intention. Hence, the model fails to provide sufficient explanations for teachers' unsuccessful integration of technology within their professional practice (Tondeur et al., 2013). Liu et al. (2019, p. 2538) suggest a list of four intention-behavior potential constraints with a direct influence on teachers' technology behaviour: habit, experience, knowledge, and facilitating conditions.

Ertmer (1999) describes two types of barriers that impact teachers' use of technology in the classroom and explores their continual interactions: the first order or external barriers (e.g., institutional, acquiring technical skills needed to operate a computer) and the second order or internal barriers (e.g., fundamental beliefs such as beliefs about computers, beliefs about teaching and learning, pedagogical concerns, current practices, thus, leading to new goals, structures, or roles). Ertmer (2005) argues that the decision on whether and how to use technology for instruction ultimately depends on the teachers themselves and the beliefs they hold about technology. She suggests addressing both first and second order barriers simultaneously. In 2007, Hew and Brush mention the gap between the importance of integration of technology in education and the barriers that persist in this process. Out of a total of 123 barriers identified from past empirical studies between 1995 and 2006, 
they condense six main categories: (a) resources, (b) institution, (c) subject culture, (d) attitudes and beliefs, (e) knowledge and skills, and (f) assessment. They then provide recommendations for addressing these gaps. For Hew and Bush, teachers' attitudes toward the integration of technology may be conceptualized as teachers liking or disliking the use of technology.

\section{The Ideal Language Teacher}

Identification of the attributes of an ideal language teacher has been a significant area of interest for many researchers. Girard's study (1977) enumerates characteristics such as "makes the course interesting, teacher's good pronunciation, explains clearly, speaks good English, shows the same interest in all the pupils, makes the pupils participate and shows great patience" (p. 100) as the most cited attributes by teachers. Prodromou's results (1991) list characteristics of an ideal language teacher valued by learners as "friendly, gave good notes, played games, told jokes, did not push weak learners, more like a comedian" (p. 2). Brosh (1996) describes characteristics of the effective language teacher as perceived by language teachers and students as "knowledge and command of the target language"; "ability to organize, explain and clarify, as well as to arouse and sustain interest and motivation among students"; "fairness to students by showing neither, favouritism nor prejudice"; and "availability to students" (p. 133). Borg (2006) studies the distinctive characteristics of language teachers, specifically of English as a foreign language (EFL) teachers, and how these characteristics are understood by language teachers. It has been suggested that positive qualities such as professional, systematic, organized, reliable, confident, active, and intelligent are associated with concepts of an ideal teacher (Chen \& Lin, 2009).

After a comprehensive literature review on the "ideal language teacher," Al-Khairi (2015) suggests that most classifications divide characteristics of an ideal language teacher into two "personal" and "professional" components. For example, characteristics such as ". . f familiarity, compassion, and enthusiasm and closeness ... perceived corporal and emotional nearness of the teacher towards their student..." (Walls et al., 2002, p. 40) are associated with the teacher's personality. Raymond (2008) describes professional skills or ability skills as "learned or practiced cognitive and psychomotor skills such as the ability to operate a computer or an overhead projector, or the ability to effectively relate difficult theoretical topics to real-life examples" (p. 17).

In our study, we decided not to divide attributes cited by participants into personal and professional components. Instead, we propose to use the term "transversal competences" or "generic competences," which include capacities such as "time management" (Serrano et al., 2011, p. 36), "flexibility" (Serrano et al., 2011, p. 37), "analysis and synthesis," "applying knowledge in practice," "general knowledge in the field of study," "capacity for generating new ideas," "appreciation of diversity and multiculturality" 
(Serrano et al., 2011, p. 39). These competences, transferable in multiple contexts and rooted in both personal and professional components, can be acquired and evolve during diverse experiences.

\section{Research Purpose and Questions}

Due to the scope of this article, only two of the four TPLang21 network objectives cited above will be addressed. These objectives resulted in the following research questions:

Research Question 1: What are the technology training needs of today's teachers of English as a Second/Foreign Language (ESL/ $\mathrm{EFL}$ )? To what extent are these needs different from the technology training needs of teachers of other languages? Are the technologyrelated training needs of ESL/EFL teachers different from the needs of language teacher trainers? Are teachers satisfied by the training they received?

Research Question 2: To what extent has the digital revolution affected the definition of the ideal language teacher?

We are particularly interested in investigating the essential needs of teachers of English to be able to provide recommendations on the elements teacher-trainers could focus on to meet the needs of their trainees.

\section{Method}

\section{Sample}

For the first phase of the study, we created an online questionnaire, using Survey Monkey, for language teachers, trainers, and administrators to share via national or international networks. This questionnaire was designed by a culturally and linguistically diverse team of eight researchers. The goal of this questionnaire was to examine the similarities and differences between the CPD needs across countries, the training models among institutions, and the different types of certification required to become a language teacher. The goal was also to explore beliefs about "ideal" teacher images and the digital revolution from a cross-cultural perspective.

\section{Measure}

The questionnaire included 32 questions, divided in four sections:

- Part 1-Participants' personal and professional information: teacher/ trainer/administrator, country, language and proficiency level taught, 
and/or language training and proficiency level taught (Closed-ended [scales], questions 1-11, with open-ended "other" options)";

- Part 2-Information on the country's current models of training for technology integration in language education, including questions such as the following: What is available? Who are the providers? What are the training formats? What works? What is required in each context? (Closedended [scales], questions 12-26, with open-ended "other" options);

- Part 3-Participants' perceptions of needs regarding teaching language education and technology (Open-ended questions, 27-29);

- Part 4-Participants' perceptions of the "ideal" teacher and the relation of these perceptions to their use of technology (Open-ended questions, 30-32).

The first two parts contain more closed-ended questions about the participants' career stage, country, level of teaching or training, type of certification offered in specific countries, and the type of technology used in classrooms. The last two parts include open-ended questions about participants' needs and perceptions. The questionnaire was translated into six languages (English, French, German, Persian, Portuguese, and Spanish).

\section{Procedure}

\section{Data Collection}

The survey was conducted during the summer of 2018 across national and international networks for language teachers, trainers, and administrators, and shared on the social media platforms Facebook and Twitter. Each country had a principal investigator who was responsible for disseminating the survey. A total of $285^{4}$ language professionals from 30 countries responded to the survey: 250 self-identified as language teachers, 145 as teacher-trainers, 46 as administrators, and 34 were from language education-related professions. Most of the survey participants (teachers and trainers) work at universities (154 teachers vs. 74 trainers), language institutes (62 teachers vs. 56 trainers), and secondary schools (58 teachers vs. 58 trainers). The five countries most represented in the survey are Canada (28\%), Argentina (17\%), Brazil (15\%), France $(10 \%)$, and the United Kingdom (8\%). The main languages taught by respondents are English (55\%), French (26\%), Spanish (6\%), and German (4\%). Most participants teach in universities (35\%). A smaller number of participants work in language institutes (14\%) and secondary schools (13\%).

\section{Analysis}

We employed a summative content analysis approach to analyze data. Unlike other types of content analysis that start with predetermined categories imposed on the data, the summative content analysis approach is an inductive analysis that starts with the counting and comparison of words or 
manifest content in data, followed by analysis and interpretation, "to include latent meanings and themes" (Zhang \& Wildemuth, 2009, p. 309). In summative content analysis, the goal is "to explore the usage of the words/indicators in an inductive manner" (Zhang \& Wildemuth, 2009, p. 309).

For our research, the quantitative data of the questionnaire (scale ratings of countries, level of teaching or training, language taught, programs available, etc.) was downloaded from the survey platform SurveyMonkey and analyzed using the software Statistical Package for Social Sciences (SPSS). Frequencies and descriptive statistics for the quantitative demographic survey items (multiple-choice, numeric responses) were calculated.

For the qualitative data (open-ended questions analysis), we used NVivo 12. As mentioned, rather than relying on preformed ideas, our data analysis began inductively, by looking for patterns among each theme. We ensured a consensus among the whole team, regarding overall coding, by sharing the development of codes and categories among the principal researchers iteratively. Each response was read multiple times to identify patterns of beliefs expressed by each participant. Our data interpretation followed concepts or variables from the literature review included above.

\section{Results}

\section{Needs:}

- What are the technology training needs of teachers of ESL/EFL? To what extent are these needs different from the technology training needs of teachers of other languages?

To answer this question, we provided some examples, such as, "use of specific software," "use of course management platforms like Moodle," "pedagogy enhanced by technology," "designing learning tasks enhanced by technology," "training in design/delivery of blended, online courses." We did not distinguish participants' needs for preservice or inservice training.

A total of 71 English teachers and 22 teachers of other languages, from 21 countries and from eight diverse ESL/EFL contexts, replied to this question.

Based on their responses, we observed that regardless of the language taught, needs such as "learning task design" skills (33.8\% of quotes from English teachers vs. $20 \%$ of quotes from teachers of other languages), "course management platforms" ( $24 \%$ vs. $9 \%)$, "pedagogy enhanced by technology" ( $21 \%$ vs. $10 \%$ ), and "blended/online courses" skills (16\% vs. $15 \%)$ are the most frequently cited needs by teachers. The need for specific software uses appears after these needs.

ESL/EFL teachers mention the need for learning the use and management of Moodle as a free platform for their teaching ( $24.6 \%$ of citations) in second place, while teachers of other languages mention the need for learning about 
Moodle in fifth place (9\%) after claiming needs for "Pedagogy enhanced by technology" (20\%), "need for certification" (15.3\%), and "teaching online or hybrid courses" $(15 \%) .^{5}$

- Do language teacher trainers mention different needs compared with the needs mentioned by teachers?

A total of $23 \mathrm{ESL} / \mathrm{EFL}$ language teacher trainers and 9 Other Language (OL) trainers from five countries responded to this question. These trainers come from five diverse contexts ${ }^{6}$. The results show an alignment between the ESL/ EFL and OL teachers' and teacher trainers' expressed needs: Task design $(25 \%)$ and pedagogy enhanced by technology $(17 \%)$ are most frequently cited and placed above the need to learn specific software applications (15\%).

- Are teachers satisfied by the training they received?

We analyzed 66 responses to this open-ended question qualitatively and identified three main categories and 16 subcategories. The respondents commented on three macro categories in terms of training: aspects of training, applicability/relevance of training in their context, and the level of institutional support/recognition. Under "aspects of training," participants report their level of satisfaction with the following: form of delivery, content relevance, trainer specificity to language teaching, theory and practice (balance, hands-on, practical/theoretical aspects: affordances for learning), duration/intensity/depth, empowerment, personalization, interaction opportunities, posttraining follow-up, and community building.

The results show that respondents rate the training received highly, in terms of form of delivery, trainers, and self-empowerment. Individual responses confirm this positive perception:

The format was very interactive (after each section of the training, we answered a writing prompt in the class forum, and then we were asked to choose one other participant's submission and leave a comment. I was surprised at how effective this was at promoting good dialogue, and I learned a lot from the other participants, something I've rarely been able to say about online courses. (English teacher, university/postsecondary, United States)

Yes, Taken on a voluntary basis, they (training programs) were chosen to address my needs at a certain time of my career. (English teacher, university/postsecondary, France)

Yes, Relevant and easy to apply. (English teacher, university/postsecondary, Argentina)

However, teachers' expectations were not satisfied in other areas, such as timeliness or specificity of content, balance between theory and 
practice. They indicate a need for more hands-on practice, increased duration, intensity, and depth.

It was mostly a useful chance to reflect rather than to receive useful resources, except for peer training. (Researcher/English teacher; university/postgraduate, Argentina)

The latest thing I did online with a 120-hour workload was focused only on the theory of using digital technologies in the English teaching classroom. (English teacher, university/postsecondary, Brazil)

Many courses in the area of continuing education of English-speaking professionals, mainly those related to the area of Communication and Information Technologies, which I have been doing, are still very theoretical, refraining from putting into practice the use of new technologies related to education. (English teacher, university/postsecondary, Brazil)

Some participants also note a lack of satisfaction regarding posttraining, applicability/relevance to their personal needs or their context, access to technology, the curriculum, and institutional support/recognition.

One professional program I took offered through ... - a Certificate program in online English language teaching/learning was usefulbut there tends to be very little out there for language teachers on technology use. (English teacher, university/postsecondary, Canada)

The training gives a general idea, but perfection comes from practice, it is completely normal. I prefer a follow-up after the training. (English teacher, university/postsecondary, Argentina)

The training I have followed in companies (language schools) is very brief and therefore insufficient in my opinion in relation to all the possibilities for further learning at this level. (English teacher, college, France)

There was no significant difference across ESL/EFL teachers and OL teachers in terms of satisfaction. For example, $62 \mathrm{ESL} / \mathrm{EFL}$ teachers and 26 OL teachers answered the question "Are you satisfied by the training you received/ offered?" affirmatively (40 ESL/EFL teachers responded Yes; 16 Yes and No; 6 No. A total of 14 OL teachers answered Yes; 8 Yes and No; 4 No). Satisfaction regarding the content and empowerment was more frequently quoted by ESL/EFL teachers (6 times) in comparison with OL teachers (once). 


\section{"Ideal" Language Teacher Perception and Digital Revolution}

- To what extent has the digital revolution affected notions of the "ideal" language teacher?

The participants were asked to write a minimum of three characteristics that they think define the "ideal" language teacher. A total of 65 ESL/EFL language teachers from 16 countries and 29 OL teachers from 12 countries responded to this question.

The qualities quoted most frequently to determine excellence are a combination of three or more "transversal competences" (33\% for English teachers and $34.3 \%$ for OL teachers). Flexibility or adaptability (cited 28 times [flexibility 21 times and adaptability 7 times]); creativity and innovation (cited 18 times [creativity 14 times, innovation 4 times]); and open-mindedness (cited 13 times), are the three transversal qualities most frequently acknowledged as criteria of excellence in language teaching ${ }^{7}$.

The following are quotes from ESL/EFL teachers:

Resourceful, active, adaptable (English teacher, secondary school, Argentina)

Ready to learn, enthusiastic and adaptable (English teacher, primary school/college, Spain)

Flexible, up-to-date, creative (English teacher, primary school, Canada)

Creative, honest, optimist (English teacher, language institute, Canada)

Flexible, compassionate, open minded (hearted) (English teacher, college, Canada)

And from OL teachers:

Curiosity, risk taker, good learner (French teacher, primary school, Canada)

Dynamic, creative, learner (Spanish teacher, language institute/ freelance, Canada)

Dedicated, passionate and creative (French teacher, junior high school, Canada)

Lifelong learner, adaptable, organized (French teacher, primary school, Canada) 
Good communicator, open, flexible (French teacher, university/postsecondary, United States)

After the "transversal competences" ranked as the first level of excellence, $28 \%$ of English teachers combined three qualities from three different categories of "pedagogical knowledge," "content knowledge," and "transversal competence" as three essential qualities of an excellent language teacher. After flexibility, creativity, and open-mindedness, the quality that determines excellence is "language knowledge" (cited 13 times).

Qualities mentioned by ESL/EFL teachers:

Patient, knowledgeable, interested in promoting learning (English teacher, university, Argentina)

Culturally and linguistically open-minded, eagerness to keep learning, willingness to constantly improve the teaching, methodical, but not too obsessed with perfection in class (English teacher, university, Spain)

Thoroughly knowledgeable in applied linguistics, language teaching methodology, adaptable, inquisitive, approachable, people-centred (English and French teacher, university, United States)

Knowledge of the subject, social conscience, continuous training (English teacher, university, Brazil)

And by OL teachers:

Energetic, capable of improvisation, fun loving, yet task oriented and an excellent speaker of the target language (French teacher, secondary school, Canada)

Enthusiasm for language and culture and imparting it to students, flexibility, awareness of various pedagogical methodologies (French teacher, college, Canada)

Good communication with students, good knowledge of relevant subject matter, flexibility to adapt teaching to facilities and equipment (English teacher, secondary school, Austria)

Other descriptions that mention only pedagogical knowledge or only content knowledge, or combine pedagogical and content knowledge or content and transversal knowledge, represent only $6 \%$ of responses.

In the definition of the "ideal" teacher, only a few teachers $(8 \%)$ mentioned using technology as one of the characteristics of excellence for teaching a language. For these teachers, technology contributes to the excellence of 
teaching if combined with transversal competencies, pedagogical and content knowledge. Using technology is never quoted alone as a criteria of excellence.

However, the transversal competencies such as flexibility, creativity, and open-mindedness mentioned above may underline teachers' willingness to integrate technology in their language classroom as an innovative and flexible pedagogical approach to language teaching and learning. Indeed, the results of a subsequent question where participants were asked if they thought there is a relation between the use of technologies and excellence in language teaching show that they replied positively or negatively to this question, independently from their beliefs about flexibility, creativity, and open-mindedness.

\section{- Do you think there is any relation between the use of technologies and} excellence in language teaching?

A total of $78 \mathrm{ESL} / \mathrm{EFL}$ language teachers and $49 \mathrm{OL}$ teachers responded to this question. Based on the results, the language taught was not a significant variable for interpretation: $39 \%$ of ESL/EFL teachers versus $45 \%$ of OL teachers totally agreed with the relation between the use of technology and excellence in teaching. "Highly correlated in today's scenario" was the most frequent reason cited by teachers, followed by student-centred explanations, such as student engagement being maximized with technology. For these participants, "technology contributes to motivating students" and "especially with younger learners, technology allows the learning to take place in a fun and stimulating environment and can help to enhance excellent language teaching." Typical of an ambivalent stance toward technology is the following statement: "It [technology] is not compulsory for excellent language teaching but has a lot of advantages."

Similarly, 35\% of ESL/EFL teachers versus 33\% of OL teachers partially agree that the use of technology positively impacts the quality of the teacher. Most explanations relate to the priority of pedagogical knowledge (when and how to use technology in meaningful ways): "Yes, if the teacher knows how to use [technology] to enhance teaching and learning"; "affordances are not just inherently put in tech tools but are realized or materialized by teachers who enjoy sufficient pedagogical competence and who can exploit them, and the same applies to constraints."

Finally, $26 \%$ of ESL/EFL teachers and $22 \%$ of OL teachers gave negative answers to this question. These participants emphasize more internal or second order barriers, based on their personal fears: "What will I do if the technology fails and my lesson can't proceed?"; “Technology could form a physical barrier, especially for the teacher who demonstrates great proficiency in face to face interaction settings." Technology is also seen as a negative factor as it "adds an additional workload." External or first order barriers such as time management and technical issues are cited as secondary factors. For these respondents, other components of teaching, such as pedagogical 
knowledge and affective areas (empathy, human contact, and love of language), rather than the use of technology, determine excellence.

Results also indicate that there is no significant correlation between inclusion of the three transversal competences cited above and a positive perception of teachers about excellence and technology use. The notions of "flexibility," "student centred," "learning styles" cited in the definition of the ideal teacher seem to have different meanings in the perceptions of participants. For example, in some responses (49\%), the notion of "student centred" links positively to the relation between excellence and use of technology in the classroom, while in other responses (51\%), it means,

be enough prepared and teach a class whether [students] only have a wooden stick to trace letters on the sand or whether they have an allsinging, all-dancing interactive whiteboard with access to an online repository of resources or lesson plans.

For some participants, the technology "is a tool to enhance the language learning or teaching but not a criteria"; as "it depends on how effectively teachers use" it. For them, "to a certain extent, there are many ways to teach/ learn [and] languages and technologies can become a part of all of these."

The following are examples of three qualities mentioned by participants, and their perceptions concerning the relation between excellence and use of technology:

\begin{tabular}{ll}
\hline Three Characteristics of Excellence & $\begin{array}{l}\text { Relation between Excellence and } \\
\text { Technology }\end{array}$ \\
\hline $\begin{array}{l}\text { Ready to learn, enthusiastic and adaptable } \\
\text { (English teacher, university, Canada) } \\
\text { Culturally and linguistically open-minded } \\
\text { (English teacher, secondary school, Germany) }\end{array}$ & Not sure \\
$\begin{array}{l}\text { Flexible, up-to-date, creative } \\
\text { (English teacher, primary school, Canada) } \\
\text { Creative, honest, optimistic } \\
\text { (English teacher, college, Canada) } \\
\text { Empathetic, creative, enthusiastic } \\
\text { (English teacher, university, France) }\end{array}$ & No \\
\hline
\end{tabular}

\section{Discussion}

In summary, the results outlined above report needs cited by teachers such as learning task design skills, course management platforms, pedagogy enhanced by technology, and more blended/online courses. The need for specific software uses appears after these needs. The results also show that respondents positively rate the training received for the integration of tech- 
nology in their classroom, especially in terms of form of delivery, trainers, and self-empowerment. However, teachers' expectations were not satisfied in other areas, such as the content currency of training, the specificity of content, or balance between theory and practice. The need for posttraining follow-up, more hands-on practice, increased duration, intensity, and depth are also highlighted. This result aligns with Kessler's report (2018) about the inadequacy, and outdated characteristics, of existing software training for language teachers.

Regarding the perception of qualities inherent in the "ideal" language teacher, the "transversal competences" such as flexibility or adaptability, creativity and innovation, or open-mindedness are the ones most frequently acknowledged as criteria of excellence. However, although one might assume that an innovative and open-minded teacher would embrace technology to offer a more flexible learning experience to their students, findings show no correlation between these transversal competences and a positive perception by teachers about the use of technology in the classroom. Indeed, when asked about the relation between the use of technologies and excellence in language teaching, teachers' responses did not correlate with their beliefs about flexibility, creativity, and open-mindedness. This contradiction, alongside the list of needs above, seems to confirm a general conclusion: Even though numerous researchers have highlighted the importance of the ability to identify the affordances of new tools, the "potential that teachers perceive in a particular technology tool" and support that it provides to learning and teaching (Haines, 2015, p. 166), current CPD programs have not been able to transfer these competences to their trainees.

According to Sykes (2017), "the teaching and learning of pragmatics ... should take advantage of digitally-mediated interaction as an essential mechanism for learners to interact with one another and members of communities in which the target language is spoken" (p. 123). However, our results imply that techno-pedagogical competences or "pedagogically appropriate technology integration" (Tochon \& Black, 2007, p. 296) have not yet been recognized by language teachers as a fundamental skill required for the needs of their students. Despite our respondents repeating theoretical points of view concerning the advantages of integration of technology in the language classroom that they learned in their training programs, they do not consider techno-langua competency to be a necessary skill. Hence, we believe that current and future CPD should maximize the "reflective process of finding appropriate matches between technology's affordance and teachers' individual pedagogical priorities" (Tochon \& Black, 2007, p. 296). Teachers also need to be able to assess the affordances of technology in relation to their local contexts and students' needs, as Lafford (2009) suggests.

Our results confirm the need for both pedagogical and technical training in ICT but also highlight precise items, which need to permeate language teacher education curricula. These suggest an overall evolution of needs, as 
outlined in the section that follows, in comparison with the needs raised in our previous studies in 2015.

\section{Task Design}

The answers show an evolution in first order needs in comparison with a previous study carried out in Europe (Germain-Rutherford \& Ernest, 2015) with similar aims. In terms of first order needs such as digital skills, GermainRutherford and Ernest show that, in 2015, the teachers

had passed the stage of using ICT just to present learning material and to develop online exercises or quizzes, and that they wanted to explore, in decreasing order of importance, Web 2.0 tools to foster learning via social interactions and collaboration, tools to create digital audio documents and course management platforms to organise and distribute course material. (p. 17)

The results outlined above indicate that ESL/EFL teachers now express the desire to become autonomous with regard to "learning task design" skills. They seem interested in learning to manage the macro organization of the content (task design) rather than micro elements such as learning to use a specific digital tool for assessment. The form of delivery (design, digital language pedagogy, online, or blended formats) and communication or the mediation of knowledge are given priority over the simple delivery of skills related to content. An understanding of the bigger picture for a teaching session integrating technology appears necessary to help language teachers gain more confidence. This point also aligns with the few comments that we received from trainers. In addition, the result seems to suggest language teachers' awareness of the fast-changing nature of digital teaching resources and the need to be able to effectively manage this overwhelming range of tools. Language teaching enhanced by technology should, henceforth, be considered as a type of teaching with its own specific characteristics.

\section{Moodle}

Unlike previous research, where wikis and blogs were the most frequently mentioned needs by language teachers (Germain-Rutherford \& Ernest, 2015), Moodle now takes the first place in terms of technical tool training needs.

Our study cannot determine whether interest in Moodle is the result of increased access by more institutions who use it as their main learning management platform, or because ESL/EFL teachers are trying to autonomously develop their online teaching skills by using Moodle, an open-source course management platform. The results also seem to show a growing interest of ESL/EFL teachers in teaching successfully online by using online tools they either would be expected or would like to use. It could also indicate a growing desire to participate in the "open learning" and "open teaching" trend 
and to become an autonomous and independent producer of knowledge by creating open educational resources.

In short, this movement from the need to develop online exercises or quizzes to task design and Moodle management aligns with the order in which Guichon and Hauck (2011) list different levels of skills in "techno-pedagogical competences." The needs to handle basic tools and applications and solve simple technical problems are ranked by Guichon and Hauck in first and second places, and the need to design appropriate tasks, as well as the need to design for interactions within and outside the classroom in view of technologies' affordance, are listed in fourth and fifth place in their classification. Hence, it seems that needs for techno-pedagogical skills among teachers have moved in a progressive manner from one stage to the next.

\section{Pedagogical Knowledge}

Sauro and Chapelle highlight "[ $\mathrm{t}]$ he fact that much of students' language use out of the classroom is mediated through technology is enormously important for language teaching" (2017, p. 461). They add that "[b]ecause contexts of language learning and use are rapidly changing, teachers and materials developers need a mechanism to incorporate innovation into teaching. In other words, the practice of seeking out, creating, and trying innovative approaches to teaching needs to become normal" (2017, p. 461).

However, according to our findings, the pedagogical competence that teachers need to develop to suit the changing dynamics of increasingly technology-mediated classroom practices remains one of the most important needs of teachers. Cited as the third most important need, it seems to show the persistence of a lack of a clear vision regarding technology integration in the language classroom. It also links to two other needs: "task design skill" and "learning management platforms," which emphasize a different level of integration requiring specific software and appropriate pedagogy. Participants clearly need to improve their ability to assess the affordances of new tools and to reflect on the affordances that match their own pedagogical priorities.

\section{Diagnostic Phase, Posttraining Follow-up, and Personalization}

An analysis of the level of satisfaction shows a high satisfaction overall regarding teacher training received. However, many teachers feel that while they may receive training in using ICTs in the classroom, the resources available are still inadequate. In addition, they mention a lack of satisfaction regarding posttraining resources. These shortcomings could be addressed by a diagnostic phase before offering training courses. Adjusting training programs to the levels and needs of teachers and making them more relevant would seem effective in assisting teachers to adapt new technology knowledge to suit their teaching context. In the majority of responses, technology is 
considered a tool that can enhance the learning or teaching but not a criterion in itself. Some of the teachers who believe that technology must be integrated in the language classroom see this necessity as a way of adapting to changes in society.

\section{Redefinition of the "Ideal" Language Teacher}

Although most participants fully or partially agree with the relationship between technology and excellence in language teaching in their direct responses, their definition of the ideal language teacher rarely includes the use of technology. A total of $33 \%$ of participants share the belief that transversal competencies are the most important factors needed to achieve excellence in language teaching.

When looking for a reason for this gap or inconsistency, we observe that some teachers who believe that technology should be integrated in the language classroom see this necessity as a way of adapting to societal change or fashion. There are no comments that mention, for example, that technology would be a form of multidisciplinary learning aligning with action-oriented methodology that promotes "student learning through collaborative involvement in authentic, challenging, multidisciplinary tasks by providing realistic complex environments for students inquiry" (Ertmer, 1999, p. 50). This may indicate that even if the awareness of a rapidly changing society pushes teachers toward adopting technology in their courses, it has not yet become an internal belief or a philosophy of language teaching in the 21st century. It, therefore, seems necessary to integrate the following discussion points into the curricula of training programs for language teachers to stimulate reflection: the definition of the ideal language teacher and the role of technology in the language classroom, as well as the techno-pedagogical component of a language teacher's professional practice.

\section{Conclusion}

In many contexts, there is still insufficient training in ICTs (Kessler, 2018). Almost 13 years after their publication, the recommendations of Hubbard and Levy (2006a) still need to be implemented. Regularly revisiting teachers' first order and second order needs in terms of integrating technology into the classroom would help to update current practices of training in institutions and make them more effective or efficient.

ESL/EFL teachers were part of the first cohort of educational professionals who adopted ICTs, and they are always seen as early adopters in the educational digital revolution-possibly because of the dominance of the English language on the internet. However, it seems that fundamental beliefs about language teaching enhanced by technology have not changed at the same pace as institutional adoption of technology, and these beliefs can, in 
fact, hinder pedagogical innovation. Raising awareness of meaningful uses of technologies and providing valuable means of support for their progress are necessary in the current context to truly transform language education for the 21st century.

\section{Limitations and Future Directions}

For the purpose of this article, data collection was specifically guided by our interest in examining the correlation between the needs of ESL/EFL teachers, their perceptions of beliefs related to the concept of the "ideal" teacher, and excellence in teaching, as well as the level of their satisfaction regarding training received. We are aware that the initial results do not reflect all the aims of our research.

In addition, the data collected and the initial findings of the first phase of the research do not fully reflect the range of cultural differences because of a significant imbalance between the number of participants from different countries. Moreover, because the questionnaire was distributed through university contacts (TPLang21 Network), most respondents are from universities (152 participants from universities vs. 62 participants from language institutes and 58 participants from secondary schools). We are aware that we need to broaden our survey to include more schoolteachers. In 2020, we aim to launch the second round of our survey with more specific questions and more opportunities for open answers.

In the future, we also plan to include a student perspective in our research, as we consider it relevant to examine students' point of view of the techno-langua competency of their teachers.

Finally, once we have established initial training needs and necessary skills, in subsequent stages, we also aim to provide much-needed practical guidance for trainers.

\section{Notes}

1. By self-empowerment, we mean giving language teachers enough self-confidence to use technology autonomously and actively in their classroom. The feeling of self-confidence depends, on one hand, on overcoming internal fears, such as the fear of losing control in front of the learners (Peters, 2006; Guichon \& Hauck, 2011), and, on the other hand, on the degree of perceived ease of access to and usability of tools and the perceived added value in terms of pedagogical practices (Kessler \& Plakans, 2008).

2. Kessler (2018) lists collaborative approaches, mashups, automation, augmented and virtual reality, artificial intelligence (AI), and big data and corpora. 
3. Great care was taken to ensure respondents' data privacy and that respondents' data cannot be traced back to individuals.

4. Because many participants have more than one professional role, the total number for all professional roles exceeds 285 .

5. The number of English teacher participants (70) is twice that for teachers of other languages (35).

6. Most of the participants who answered this question worked, respectively, in higher education, secondary or primary schools.

7. Other transversal competencies are, respectively, "open to learn" (cited 11 times), "passion" (cited 11 times [passion 7 times and enthusiasm 4 times]), "patience" (cited 8 times), and "empathy" (cited 7 times).

\section{The Authors}

Banafsheh Karamifar, $\mathrm{PhD}$, is researcher and part-time professor in both the Faculty of Arts and the Faculty of Education of the University of Ottawa, Canada. Her research interests include technology-enhanced language learning, literacy in higher education, discourse analysis, and corpus linguistics.

Aline Germain-Rutherford, PhD, is Vice-Provost, Academic Affairs, and full professor at the Faculty of Education at the University of Ottawa, Canada. Her research and publications focus on second language pedagogy, speech technology, and the integration of active pedagogy in e-learning practices.

Sarah Heiser, MA, is a senior lecturer in the School of Languages and Applied Linguistics at the Open University, UK. She is Associate Dean, Student Tuition in the Faculty of Wellbeing, Education and Language Studies. She is an experienced academic line manager with interests in technology-enhanced language learning and teacher development by experiential learning in online spaces.

Martina Emke, EdD, is an affiliated researcher at the Open University, UK. She is an experienced English teacher and teacher educator. Her research interests include networked learning, social media, algorithmic education, and posthuman research approaches.

Joseph Hopkins, MA, is director of the Centre for Modern Languages at the Open University of Catalunya. His research interests are CALL (Computer-Assisted Language Learning), training of language teachers in the use of information and communication technologies (ICTs), distance language learning, computer-supported collaborative learning, and computer-mediated communication.

Pauline Ernest, $\mathrm{PhD}$, is a former director of the Language program and coordinator of language courses at the Centre for Modern Languages at the Open University of Catalunya. Her research interests include language learning in online environments, computer-supported collaborative work, and the training of language teachers in the use of ICT in the classroom.

Ursula Stickler, $\mathrm{PhD}$, is senior lecturer in the School of Languages and Applied Linguistics at the Open University, UK. She is an experienced distance and online language teacher and teacher educator. Her research focuses on technology-enhanced language learning and qualitative research methods. 
Regine Hampel, $\mathrm{PhD}$, is full professor of Open and Distance Language Learning at the Open University, UK, and currently holds the role of Associate Dean (Research Excellence) in the Faculty of Wellbeing, Education and Language Studies. Her research interests include use of digital technologies for language learning and teaching.

\section{References}

Al-Khairi, M. (2015). Qualities of an ideal English language teacher: A gender-based investigation in a Saudi context. Journal of Education and Practice, 6(15), 88-98.

Andrews, T., Tynan, B., \& Stewart, C. (2011). Ubiquitous learning: Issues in the Australian higher education context. In T. T. Kidd and I. Chen (Eds.), Ubiquitous learning: Strategies for pedagogy, course design, and technology (pp. 41-60). Charlotte, NC: Information Age Publishing.

Bain, A., \& Ross, K. (1999). School reengineering and SAT-1 performance: A case study. International Journal of Education Reform, 9(2), 148-153.

Bagozzi, R. P. (2007). The legacy of the technology acceptance model and a proposal for a paradigm shift. Journal of the Association for Information Systems, 8(4), 244-254.

Blake, R. (2008). Brave new digital classroom: Technology and foreign language learning. Washington, DC: Georgetown University Press.

Bonner, E., \& Reinders, H. (2018). Augmented and virtual reality in the language classroom: Practical ideas. Teaching English with Technology, 18(3), 33-53.

Borg, S. (2006). Teacher cognition and teacher education: Research and practice. London: Continuum.

Bransford, J. D., Brown, A. L., \& Cocking, R. R. (2000). How people learn: Brain, mind, experience, and school. Washington, DC: National Academies Press.

Brooks, D. C. (2016). ECAR Study of undergraduate students and information technology (Research Report). Louisville, CO: EDUCAUSE Center for Analysis and Research. https://library.educause.edu/ /media/files/library/2016/10/ers1605.pdf

Brosh, H. (1996). Perceived characteristics of the effective language teacher. Foreign Language Annals, 29, 125-136.

Bullen, M., \& Morgan, T. (2015). Digital learners in higher education: Implications for teaching, learning \& technology. In M. Gisbert and M. Bullen (Eds.), Teaching and learning in digital worlds: Strategies and issues in higher education (pp. 11-19). Tarragona, Spain: Publicaciones URV.

Chen, Y., \& Lin, S. (2009). Exploring characteristics for effective EFL teachers from the perceptions of junior high school students in Tainan. STUT Journal of Humanities and Social Sciences, 2, 219-149.

Cutrim Schmid, E. (2017). Teacher education in computer-assisted language learning: A sociocultural and linguistic perspective. London: Bloomsbury.

Darling-Hammon, L., \& Ball, D. (1998). Teaching for high standards: What policymakers need to know and be able to do. CPRE Research Reports. http://repository.upenn.edu/cpre researchreports/92

Dexter, S. L., \& Anderson, R. E. (2002, September). U.S.A.: A model of implementation effectiveness. Annual meeting of the European Conference on Educational Research. http://edtechcases. info/papers/multicase_implementation.htm

Dörnyei, Z. (2001). Teaching and researching motivation. Harlow: Longman.

Egbert, J., Akasha, O., Huff, L., \& Lee, H. (2011). Moving forward: Anecdotes and evidence guiding the next generation of CALL. International Journal of Computer-Assisted Language Learning and Teaching, 1, 1-15.

Ertmer, P.A., Ottenbreit-Leftwich, A.T., Sadik, O., Sendurur, E., \& Sendurur, P. (2012). Teacher beliefs and technology integration practices: A critical relationship. Computers $\mathcal{E}$ Education, $59,423-435$.

Ertmer, P. A. (2005). Teacher pedagogical beliefs: The final frontier in our quest for technology integration? Educational Technology Research and Development, 53(4), 25-39. 
Ertmer, P. A. (1999). Addressing first- and second-order barriers to change: Strategies for technology integration. Educational Technology Research and Development, 47(4), 47-61.

Ertmer, P. A., Addison, P., Lane, M., Ross, E., \& Woods, D. (1999). Examining teachers' beliefs about the role of technology in the elementary classroom. Journal of Research on Computing in Education, 32(1/2), 54-72.

Germain-Rutherford, A., \& Ernest, P. (2015). European language teachers and ICT: Experiences, expectations, and training needs. In R. Hampel \& U. Stickler (Eds.), Developing online language teaching: Research-based pedagogies and reflective practices (pp. 12-27). New York: Palgrave Macmillan.

Girard, Denis. (1977). Motivation: The responsibility of the teacher. ELT Journal, 13, 97-102.

Guichon, N., \& Hauck, M. (2011). Teacher education research in CALL and CMC: More in demand than ever. ReCALL, 23, 187-199.

Haines, K. J. (2015). Learning to identify and actualize affordances in a new tool. Language Learning \& Technology, 19(1), 165-180.

Hampel, R., \& Stickler, U. (Eds.). (2015). Developing online language teaching: Research-based pedagogies and reflective practices. New language learning and teaching environments. New York: Palgrave Macmillan.

Hampel, R., \& Stickler, U. (2005). New skills for new classrooms: Training tutors to teach languages online. Computer Assisted Language Learning, 18, 311-326.

Hanson-Smith, E. (2006). Communities of practice for pre- and in-service teacher education. In P. Hubbard \& M. Levy (Eds.), Teacher education in CALL (pp. 301-315). Amsterdam: John Benjamins.

Hubbard, P. (2007). Critical issues: Professional development. In J. Egbert \& E. Hanson-Smith (Eds.), CALL environments: Research, practice and critical issues (2nd ed.) (pp. 276-292). Alexandria, VA: Teachers of English to Speakers of Other Languages.

Hubbard, P., \& Levy, M. (2006a). Introduction. In P. Hubbard \& M. Levy (Eds.), Teacher education in CALL (pp. ix-xi). Amsterdam, Philadelphia: John Benjamins.

Hubbard, P., \& Levy, M. (2006b). The scope of CALL education. In P. Hubbard \& M. Levy (Eds.), Teacher education in CALL (pp. 3-20). Amsterdam, Philadelphia: John Benjamins.

Hew, K. F., \& Brush, T. (2007). Integrating technology into K-12 teaching and learning: Current knowledge gaps and recommendations for future research. Educational Technology Research and Development, 55, 223-252.

ICT Cluster. (2010). Lessons learned by the ICT cluster Education \& Training 2010 programme. European Commission. https://erte.dge.mec.pt/sites/default/files/Recursos/Estudos/key_lessons_ict_cluster_final_report.pdf

Kessler, G. (2018). Technology and the future of language teaching. Foreign Language Annals, 51(1), 205-218.

Kessler, G. (2013). Collaborative language learning in co-constructed participatory culture. CALICO Journal, 30, 307-322.

Kessler, G. (2010). When they talk about CALL: Discourse in a required CALL class. CALICO Journal, 27, 376-392.

Kessler, G., \& Plakans, L. (2008). Does teachers' confidence with CALL equal innovative and integrated use? Computer Assisted Language Learning, 21(3), 269-282.

Kessler, G. (2007). Formal and informal CALL preparation and teacher attitude toward technology. Computer Assisted Language Learning, 20, 173-188.

Kessler, G. (2006). Assessing CALL teacher training: What are we doing and what could we do better? In P. Hubbard \& M. Levy (Eds.), Teacher education in CALL (pp. 22-42). Amsterdam: John Benjamins.

Kim, Ch. M., Kim, M. K., Lee, Ch., Spector, J. M., \& DeMeester, K. (2013). Teacher beliefs and technology integration. Teaching and Teacher Education, 29, 76-85. https://doi.org/10.1016/j. tate.2012.08.005 
Kim, M. K., Xie, K., \& Cheng, S.-L. (2017). Building teacher competency for digital content evaluation. Teaching and Teacher Education, 66, 309-324.

Koehler, M., \& Mishra, P. (2009). What is technological pedagogical content knowledge (TPACK)? Contemporary Issues in Technology and Teacher Education, 9(1), 60-70.

Koehler, M. J., Mishra, P., \& Yahya, K. (2007). Tracing the development of teacher knowledge in a design seminar: Integrating content, pedagogy and technology. Computers $\mathcal{E}$ Education, 49(3), 740-762.

Kondracki, N. L., \& Wellman, N. S. (2002). Content analysis: Review of methods and their applications in nutrition education. Journal of Nutrition Education and Behavior, 34, 224-230.

Little, J. W. (1993). Teachers' professional development in a climate of educational reform. Educational Evaluation and Policy Analysis, 15(2), 129-151. https://doi. org/10.3102/01623737015002129

Liu, H., Wang, L., \& Koehler, M. J. (2019). Exploring the intention-behavior gap in the technology acceptance model: A mixed-methods study in the context of foreign-language teaching in China. British Journal of Educational Technology, 50, 2536-2556. https://doi.org/10.1111/ bjet.12824

Loucks-Horsley, S., Hewson, P. W., Love, N., \& Stiles, K. E. (1998). Designing professional development for teachers of science and mathematics. Thousand Oaks, CA: Corwin Press.

Mishra, P., \& Koehler, M. J. (2006). Technological pedagogical content knowledge: A framework for teacher knowledge. Teachers College Record, 108(6), 1017-1054.

Newhouse, C. P. (2001). A follow-up study of students using portable computers at a secondary school. British Journal of Educational Technology, 32(2), 209-219.

O'Mahony, C. (2003). Getting the information and communications technology formula right: Access + ability $=$ confident use. Technology, Pedagogy, and Education, 12(2), 295-311.

Organisation for Economic Co-operation and Development (OECD). (2019). TALIS 2018 results (Vol. I): Teachers and school leaders as lifelong learners. Paris: TALIS, OECD Publishing. https:// doi.org/10.1787/1d0bc92a-en

OECD. (2015). Students, computers and learning: Making the connection. Paris: PISA, OECD Publishing. https://doi.org/10.1787/9789264239555-en

OECD. (2012). Connected minds: Technology and today's learners, educational research and innovation. Paris: OECD Publishing. https://doi.org/10.1787/20769679

Prodromou, L. (1991). The good language teacher. English Teaching Forum, 29(2), 2-7.

Putnam, R. T., \& Borko, H. (2000). What do new views of knowledge and thinking have to say about research on teacher learning? Educational Researcher, 29(4), 4-15.

Rapport, F. (2010). Summative analysis: A qualitative method for social science and health research. International Journal of Qualitative Methods, 9(3), 270-290.

Raymond, S. M. (2008). Effective and ineffective university teaching from the students' and faculty's perspectives: Matched or mismatched expectations? Thesis submitted to the University of Exeter in part requirement for the Doctor of Education (EdD). http://eric.exeter.ac.uk

Reinders, H., \& Wattana, S. (2015). Affect and willingness to communicate in digital game-based learning. In ReCALL, 27, pp. 38-57. https://doi.org/10.1017/S0958344014000226

Reich-Stiebert, N., \& Eyssel, F. (2016). Robots in the classroom: What teachers think about teaching and learning with education robots. In A. Agah, J. J. Cabibihan, A. Howard, M. Salichs, \& H. He (Eds.), Social Robotics (pp. 671-680). Springer, Cham. https://doi.org/10.1007/978-3319-47437-3_66

Robb, T. N. (2006). Helping teachers to help themselves. In P. Hubbard \& M. Levy (Eds.), Teacher education in CALL. Amsterdam, The Netherlands: John Benjamins.

Sauro, S., \& Chapelle, C. A. (2017). Toward langua-technocultural competence. In C. A. Chapelle \& S. Sauro (Eds.), The handbook of technology and second language teaching and learning (pp. 459-472). Oxford: Wiley-Blackwell. https://doi.org/10.1002/9781118914069.ch30 
Scherer, R., Tondeur, J., Siddiq, F., \& Baran, E. (2018). The importance of attitudes toward technology for pre-service teachers' technological, pedagogical, and content knowledge: Comparing structural equation modeling approaches. Computer in Human Behavior, 80, 67-80.

Schlager, M. S., \& Fusco, J. (2004). Teacher professional development, technology, and communities of practice: Are we putting the cart before the horse? In S. Barab, R. Kling, and J. Gray (Eds.), Designing virtual communities in the service of learning (pp. 12-153). Cambridge University Press.

Sharp, S. K. (2011). Teachers acquisition of CALL expertise. International Journal of ComputerAssisted Language Learning and Teaching, 1, 1-16.

Serrano, R. M., Romero, J. A., Bolo, M. J., \& Diz Pérez, J. (2011). Student training in transversal competences at the University of Cordoba. European Educational Research Journal, 10(1), 34-52.

Sivin-Kachala, J., \& Bialo, E. R. (2000). Research report on the effectiveness of technology in schools. Washington, DC: Software and Information Industry Association.

Smylie, M. A., Allensworth, E., Greenberg, R. C., Harris, R., \& Luppescu, S. (2001). Teacher professional development in Chicago: Supporting effective practice. Consortium on Chicago School Research.

Stickler, U., and Emke, M. (2015). Part-time and freelance language teachers and their ICT training needs. In R. Hampel \& U. Stickler (Eds.), Developing online language teaching: Research-based pedagogies and reflective practices (pp. 12-27). New York: Palgrave Macmillan.

Sykes, J. M. (2017). Technologies for teaching and learning intercultural competence and interlanguage pragmatics. In C. A. Chapelle and S. Sauro, The handbook of technology and second language teaching and learning (pp. 119-133). Oxford: Wiley-Blackwell.

Thomas, S. (2016). Future ready learning: Reimagining the role of technology in education. National Education Technology Plan. Office of Educational Technology: U.S. Department of Education.

Thompson, A. D., \& Mishra, P. (2007). Breaking news: TPCK becomes TPACK! Journal of Computing in Teacher Education, 24(2), 38-64.

Tondeur, J., Kershaw, L. H., Vanderlinde, R., \& Van Braak, J. (2013). Getting inside the black box of technology integration in education: Teachers' stimulated recall of classroom observations. Australasian Journal of Educational Technology, 29(3), 434-449.

Walls, R. T., Nardi, A. H., Von Minden, A. M., and Hoffman, N. (2002). The characteristics of effective and ineffective teachers. Teacher Educational Quarterly, Winter, 29(1), 39-48.

Williams, L., Abraham, L. B., \& Bostelmann, E. D. (2014). A discourse-based approach to CALL training and professional development. Foreign Language Annals, 47, 614-629.

Wilson, S. M., \& Berne, J. (1999). Chapter 6: Teacher learning and the acquisition of professional knowledge: An examination of research on contemporary professional development. Review of Research in Education, 24(1), 173-209. https://doi.org/10.3102/0091732X024001173

Zhang, Y., \& Wildemuth, B. M. (2009). Qualitative analysis of content. In B. Wildemuth (Ed.), Applications of social research methods to questions in information and library science (pp. 308-319). Westport, CT: Libraries Unlimited. https://www.ischool.utexas.edu/ yanz/Content_analysis. pdf.

Zhao, Y., Pugh, K., Sheldon, S., \& Byers, J. L. (2002). Conditions for classroom technology innovations. Teachers College Record, 104(3), 482-515. 